\title{
Democratic consolidation, fiscal responsibility and national development: An appraisal of the fourth republic
}

\author{
Dhikru Adewale YAGBOYAJU \\ Department of Political Science, Obafemi Awolowo University, Ile-Ife, Nigeria. \\ Accepted 11 February, 2013
}

\begin{abstract}
The return of civil rule to Nigeria in 1999 brought a lot of hope for speedy national development in the country. This was because, unlike under the country's prolonged military rule, democratization was expected to usher in openness, accountability and, more importantly, fiscal responsibility. However, in the twelve years that the fourth republic has operated, there has been scant regard for fiscal responsibility. This is the crux of the matter in this paper. The paper, in its search for probable causes for this threat to democratic rule and overall development in Nigeria, identified some key factors. These include the artificial beginning of the state, colonial legacies, the abuse of the traditional patrimonial system and, more pungently, the effects of military rule as well as the attendant consequences of the general abuse of official privileges. The research methodology is essentially descriptive and analytical. It adopts and justifies some prominent explanations on the impact of an effective public finance management and administration on the overall development of Nigeria as a country. The framework of analysis shall solely rest on the mutually reinforcing effects of the relationship between an autonomous as well as functional state and the well being of its people especially when state-society relationships are less acrimonious. Recommendations, based on examples of best practices that will be drawn from selected countries, shall also be made at the end of the paper.
\end{abstract}

Key words: Democratic consolidation, fiscal responsibility, national development, fourth republic, Nigeria.

\section{INTRODUCTION}

Democracy is widely regarded in several parts of the globe as the best system of government not only because it ensures the participation of the electorate in the selection of their representatives and those who govern them, but also because it encourages transparency, openness and accountability in governance and public affairs in general. Incidentally, in virtually all the sections of the developed world, as well as in most of the prominent developing countries, democracy is well accepted as the standard norm. In this vein, the sustenance of democratic principles or the consolidation of the gains of democratization processes should be the most important goal for any country that desires development.

In the case of Nigeria, particularly since the return of civil rule and the commencement of the Fourth Republic in 1999, all the characteristics and trappings of democracy are expected to restore the country's 
developmental process that was kept in abeyance during its prolonged encounter with military rule. Rather shockingly, twelve years after the commencement of the Fourth Republic there is hardly any regard for fiscal responsibility let alone accountability and such other attributes that could make national development attainable in good time. Several questions can be raised in view of this turn of events. Why, for instance, is the legislature that is known for its oversight functions and other institutional control mechanisms, which ensure fiscal responsibility and development in many other democracies, performing so abysmally in Nigeria? Are there explanations for the ineffective implementation of huge national and regional budgets, especially allocations for capital projects that have not significantly improved the living conditions of the ordinary citizens in the last twelve years of democratization? What are the probable causes of the disconnect between the reforms in the various Ministries, Departments and Agencies (MDAs) of government that were, for instance, applauded by the African Peer Review Mechanism (APRM) and some other international agencies, particularly under the administration of President Olusegun Obasanjo (19992007), and the general well being of ordinary Nigerians? In what major ways can this evident lack of fiscal responsibility endanger the consolidation of democratic rule in Nigeria's Fourth Republic and the country's developmental process as a whole? These and several other similar questions shall primarily guide the focus of this paper.

The research methodology, which critically examines some of the prominent extant theories and explanations on the impact of sound public finance management and administration on the attainment of developmental goals, is essentially descriptive and analytical. While it attempts, for instance, to justify the explanations on the "comprehensive legislative and statutory provisions on what, how and when, and by whom public resources are to be obtained and used" it also tries to critically analyze the peculiarities in the Nigerian environment, which may either enhance or hamper the effective implementation of the postulations offered in the immediate foregoing by Kiragu (2002). The framework of analysis rests solely on the mutually reinforcing effects of an autonomous and functional modern state and its supporting components and civil society. In other words, the performance of public policies in contemporary Nigeria, which includes the effects of fiscal responsibility on democratization and public affairs in general, shall be analyzed under the prism of state-society relationships that have facilitated evident development in many parts of the world, but which is yet to manifest significantly in Nigeria.

Having done with the introduction to the paper, the remainder is arranged into four main sections. They are namely, definitional and conceptual issues; the nature of public policy processes in Nigeria; an appraisal of selected aspects of the fourth republic; and concluding remarks.

\section{DEFINITIONAL AND CONCEPTUAL ISSUES}

There is no attempt to construct ultimate definitions of terms in this paper. Nonetheless, four key terms namely; democracy, democratic consolidation, fiscal responsibility and development shall be contextualized so as to logically drive the main thesis of the paper. In the light of this, democracy shall be defined as a system of government, which not only allows mass participation by way of encouraging the electorate to participate in the selection of their representatives but also by being transparent and accountable to them. In this view, Ake (1996) is of the opinion that democracy is about principles rather than about institutional forms. For him, it is the principles of public accountability, mass participation, majority rule, and minority rights that define democracy as a concept. It follows therefore, that any political system that provides for these principles qualifies to be called a democracy, "and anyone that does not, no matter the majesty of physical infrastructure of democracy put in place cannot justifiably refer to itself as a democracy" (Mimiko, 2010:2). However, it should be emphasized that democracy thrives better in many parts of the world where there are also strong democratic institutions. In other words, democratic principles thrive and are more effective when they are supported by strong institutions of modern government. In this connection, Diamond (1999:13) aptly notes that if:

...a transition to democracy is ever to be achieved and sustained... a deeper transition must somehow be effected from prebendalism to real institutionalism, where the legal and constitutional rules function with effectiveness to constrain behaviour. This will require not simply wise imaginative institutional designs... but powerful forces and agencies to enforce them.

Drawing from the above, democratic consolidation should therefore connote a consistent and sustained practice of democratic principles. According to Asiwaju (2000), democratic consolidation "implies the internationalization of democratic culture and the institutionalization of democratic "best practices" by a polity that has successfully embarked on a democratic transition". For better clarity, democratic consolidation could be said to effectively prevail in most mature and advanced democracies of the world where many of the prominent democratic principles largely constitute the political culture.

In line with some aspects of the democratic principles that were outlined in a preceding section of this paper, the concept of fiscal responsibility can be explained as 
the process of answerability on all issues pertaining to the public or state revenue by key state officials. In many aspects of extant literature in the field of Political Science, there has been a considerable debate on whether the state, as a sovereign, should be accountable to anyone, since it was the sole guarantor of social peace, or whether the state should be treated as a moral and responsible agent (Olowu, 2002:140). The preponderant opinion in many national constitutions as well as the burgeoning Public Administration literature is that while "the state must be self-accounting on the basis of the constitution and laws of a country, the individuals who exercise state authority can be held accountable for the actions of the state they represent" (Olowu, 2002:140). Obviously, this is the core of effective public finance management and administration in most modern governments across the globe. In more concrete terms, Kiragu (2002) and Holmes (1998) at different times summarized the public financial system as consisting of:

- Proper planning and budgeting for public expenditures;

- Effective and efficient administration of government revenues;

- Proper use of budget resources;

- Effective control of public expenditures;

- Accounting and reporting on public finance; and

- Full accountability for all public spending.

Evidently, the effective management of the aspects of public life outlined above accounts for economic growth and development in most parts of the developed world. In the light of this, it is perhaps appropriate to ask about what constitutes development? Studies on development especially from the socio-cultural, economic and political dimensions acknowledge the profound contributions of scholars like Emile Durkheim, Talcot Parsons and Max Weber among several others. In most of these studies, the main thesis is that the "changes which brought out the most fundamental transformation and eventually induced development, began from value system" (Onuoha, 2007:58). In simple terms, development as characterized by the transformation from the traditional and mechanical mode of production to the organic that emphasizes division of labour and ensures higher productivity and prosperity is essentially all about change in the value system. Meanwhile, the value system refers to the norms, beliefs, attributes and habits, which help to define what is good or bad, important, worthwhile, desirable and worth striving for, in any particular society (ibid).

Therefore, as it is outlined above, development can be defined as the:

... process of actualizing man's inherent capacity to live a better and more rewarding life. It implies increased skill and capacity to do things; greater freedom, self confidence, creativity, self discipline, responsibility and material well being (Nnoli, 1981)

Obviously, this definition of development shows that it entails economic growth but not limited to economics alone. Economic growth becomes more effective when it encompasses progressive or democratic political development in which every sane adult citizen has an effective participatory role in the processes that shape his or her life. It is only then that each and everyone will have a stake in the survival of the community as a social, political and economic unit (Olopenia, 1998:3).

Quite importantly, the broad and deep relationship between economics and politics that is being discussed here, and which also determines the level of development in any society, largely depends on the types of policies and the character of their implementation. In this connection, it is appropriate to critically examine the nature and character of public policy processes in Nigeria.

\section{THE NATURE OF PUBLIC POLICY PROCESSES IN NIGERIA}

It is perhaps impracticable to have any meaningful discussion on the nature of Nigeria's public policy processes or any other aspect in the operations of the modern state in the country without due cognizance of its colonial beginning and the effects of this on subsequent socio-economic and political development. The present day Nigeria had its origins in the 1914 amalgamation exercise by the British colonialists. What existed prior to this time were several diverse ethnic nationalities that had occasional economic and social relationships with each other. There were, certainly, no strong evidences on the probability of the formation or construction of a state with such a magnitude as the Nigerian structure that emerged after the 1914 exercise. Various probable reasons for the fusion of the erstwhile diverse ethnic nationalities are well covered in the expansive literature on this area of study. However, it is quite instructive to note that having been formed without substantial consent from the indigenous people, Nigeria lacked significant legitimating ideals right from the outset (Yagboyaju, 2009:329). Variously described as the "mistake of 1914", "mere geographical expression", etc, the construction obviously did not actualize the full integration of the different ethnic groups that had mutual suspicion and distrust for each other.

Therefore, it was not surprising that the colonial state was largely authoritarian in nature. In this connection and in line with its scant consideration for legitimating ideals, colonial Nigeria was variously described as "an administocracy" (Dudley, 1973), "dictatorship" and unrepresentative among several others. Nonetheless, 
colonial administration in Nigeria was able to introduce and sustain certain modern bureaucratic values. Essentially, these values and practices conformed with universal principles of development like skill acquisition, professionalism, division of labour and merit that are emphasized in the works of Max Weber, Talcot Parsons and several other development scholars; and they largely enabled efficiency.

However, all of these elements of modernization and their process began to falter as the indigenous people took over positions of authority towards the end of colonial rule. Several scholarly works have advanced explanations for the gradual drop in the efficiency of the Nigerian state and the effectiveness of its policies in the twilight of colonial rule. Most of the prominent ones, which included Lewis (1965), Dudley (1973) and Ekeh (1975), among several others, emphasized the manipulation of ethnic and primordial sentiments by many of the indigenous political elites as well as technocrats at that point in time.

In some relatively more recent explanations that were applied in studies on the character of the state in the Congo, Zaire, Uganda and Nigeria, in particular, as well as several other parts of the less developed world, the patrimonial and prebendal framework gained more currency. It should, for instance, be noted that the original Weberian idea on patrimonialism was adopted by scholars like Ergas (1987), Callaghy (1987), Theobald (1990), Joseph (1991) and Ikpe (2005), and many others to substantiate their own arguments on such conceptualizations as neo-patrimonialism, patrimonial administrative state and prebendal state in Africa and the rest of the less developed world. The common line of argument in most of these studies is that the amorphous state in Africa and the other places is manipulated by public officials with the result that there is a prevalence of nepotism, favouritism, clientelism, godfatherism, political corruption, instability and general lack of development. More importantly, there is lack of transparency, accountability and fiscal responsibility. Obviously, all of these worsened with the advent of military rule in Nigeria. Disturbingly, its exacerbation, which coincided with the most poignant period of military rule in the country, between the mid-1980s and late 1990s, is yet to abate significantly after twelve years of democratization in the country.

The net effect of all of these is that the public policy cycle in Nigeria (formulation and implementation) is still largely characterized by elements of personal rule. Apparently, a plausible explanation for this phenomenon that has pervaded Nigeria's socio-economic and political space for most of its fifty years of political independence is that most of the modern values brought about by colonial rule were "mere superimposition on old values" (Adejumobi, 1985:168). The simple interpretation of this is that the environment in Nigeria like any other place has a great impact on the character of the country's public policy processes. In the case of Nigeria, the ineffective nature of most public policies, especially in respect of accountability and fiscal responsibility, can be traced to the manipulation of the oppressive character of the colonially-contrived modern state and such negative aspect of the indigenous patrimonial system as the kabiyesi mentality (the king or patriarch should not be faulted) by the public officials to foist personal rule on the ordinary citizens. As the paper shall discuss more vividly in the next section, the adverse effects of personal rule on policy formulation and implementation as well as democratization and overall development in Nigeria, which became phenomenally pronounced particularly after the discovery of crude oil, constitute a huge challenge to democratic consolidation since the return of civil rule in 1999 largely because most of the major party and elections financiers are also those who benefited either as direct participants or acolytes in the immediate past military regimes. Similarly, many of the elected and appointed officials in the successive civilian administrations in the past one decade were also tainted by the negative aspects of the old political order.

\section{AN APPRAISAL OF SELECTED ASPECTS OF THE FOURTH REPUBLIC}

In this section particular emphasis is being placed on randomly selected aspects of Nigeria's democratization in the Fourth Republic. In specific terms, the budgetary system, intra-governmental relations and accessibility to information on government activities as well as others that are related to public finance management shall be critically examined and discussed.. To start with, the budget is typically "... a statement of how money will be raised and spent over a period of time" (Jinadu, 2010:27). In more specific terms, the budget is a policy statement of the priorities and expectations of the government, under conditions of scarcity and competing needs of various government ministries, departments and agencies (Wildavsky, 1975; Jinadu, ibid). In the light of this, the wealth and poverty of a nation therefore inexorably depends on the efficient and effective management of its budgetary process. India, Brazil, China, South Korea, Malaysia, Singapore and Vietnam are, perhaps, good examples of countries that have in contemporary times confirmed the applicability of the synergy between an effective budgetary system and economic growth. Apparently, the evident lack of significant growth in Nigeria even twelve years after the commencement of the Fourth Republic, particularly in terms of the infrastructural decay, unemployment and poverty levels, can be traced to either poor budget planning or execution, or both.

Since the budgeting process in a representative government symbolically starts with the legislature, it may be appropriate to question the process that led to the 
selection or election of Nigeria's legislators who, for instance, have a penchant of allocating huge salaries and allowances that are not in conformity to the realities in the country to themselves, and at the expense of the ordinary citizens and electorate that they represent. Instructively, both at the national and other levels of government, the major responsibility of the legislature in ensuring good governance and ensuring value-for-money as well as effective service delivery, especially in terms of the needed emphasis on capital budgets as against the recurrent aspects, is performed quite abysmally. Undoubtedly, most of the political parties that sponsored these parliamentarians operate in accordance with the country's challenge of patrimonialism and patron-client networks, as discussed in a preceding section. Therefore, they are unlikely to pick the best personnel that is required for the administration and consolidation of democratic ideals in Nigeria.

Similarly, another key arm of the public sector, the executive and bureaucracy, have a pivotal role in the budgetary process. It is involved not only in the important assignment of executing the budget but also in the phenomenally bigger intra-governmental relationship. Before proceeding into the discussion of the impact of intra-governmental relations, as espoused in the principles of separation of powers, on Nigeria's Fourth Republic, it may be necessary to also critically examine how the civil service, the core of the executive arm, derives its legitimacy in Nigeria. While the political arm derives its legitimacy from the constitutionally approved electoral exercise that is conducted every four years, the civil or public servants in the wide spectrum that includes not only the ministries and departments of the core civil service but also the agencies or parastatals, derive their legitimacy from a competitive professional process that recruits them on the ground that they are capable of implementing programmes and providing efficient and effective service (Ezekwesili, 2011:19). Obviously, this recruitment process cannot but also be affected by its ecology or environment. This shall be more vividly discussed as the paper examines some aspects of intragovernmental relationships in Nigeria between 1999 and 2011.

In view of the centrality of the budgetary process in the life of any modern government and the interlocking nature of its operations; in spite of the constitutional arrangements on separation of powers and checks and balances, this discussion on intra-governmental relationships in Nigeria shall focus more on budget planning and implementation. In the light of this, it may be necessary to reflect on the earlier position of this paper on the recruitment processes into the legislative and executive arms of Nigeria's Fourth Republic. As argued, the environment and the prebendal nature of politics combined to affect these processes and their products. However, the legislative arm is obviously more adversely affected because of the more profound influence of the society on its processes. The net effect is that the legislatures are inadequately staffed, and are ill-equipped to undertake their appropriation, investigative and oversight functions in the budgetary process (Jinadu, 2010). According to Nyong (2000), this capacity inadequacy constitutes an alienation of some of the powers and functions of the legislatures in Nigeria. Specifically, lacking budgetary expertise, competent legislative aides and research staff to conduct appraisals on the budget, the state legislatures and, to a lower degree, their federal counterpart tend to rely on information supplied by executive branch functionaries, over whom they are expected to exercise oversight (Jinadu, 2010:34).

Obviously, this inadequacy that most of the time does not allow a legislature across the country to discuss with the executives is a potential source of serious acrimony between them. Therefore, it is not surprising that most instances of disharmonious intra-governmental relationships between 1999 and 2011; when the next in the country's Fourth Republic series of general elections held, were related to public finance administration. We can further illustrate with some practical examples. In 1999, for instance, it was the non-inclusion of the operational funds for the parliament in that year's budget, which caused the first major friction after the reintroduction of civil rule. Perhaps the Abubakar military regime, which handed over to the Obasanjo civilian administration expected the successor regime to fully understand what it had to do on the issue, the latter seemed not to. Thus, the ding-dong between the legislature and executive over the issues of allowances to the parliamentarians, office and residential accommodation, and furniture as well as the supply of other necessary infrastructure took six weeks to resolve. Similarly, the request by the legislators to be directly involved in the execution of their constituency projects caused a lot of disharmony between them and the executive arms. The latter insisted that the parliamentarians were, constitutionally, only expected to identify projects for which allocations are made in the budgets of particular years.

At the state and local government levels, the story has not been totally different. For instance, in Abia, Adamawa and Lagos states under Governor Peter Obi, Murtala Nyako and Babatunde Raji Fashola respectively, there were threats of impeachment, at different points in time, over budget related issues. In such other states as Osun and Oyo, under Governor Olagunsoye Oyinlola and Christopher Alao-Akala respectively, the relationship between these two arms of government was less acrimonious most probably because the executive arms in the two states were more flexible, particularly in terms of the execution of constituency projects and provision of other financial allowances to the parliamentarians. However, this is not to say that this position is constitutionally right. The case of Ogun State, under 
Governor Gbenga Daniel, is more troubling. Here, the chain of political events, which first divided the House of Assembly into two camps of 15 legislators against 9, later led to the removal of Mrs. Titi Oseni as the Speaker of the House. Obviously, the latter and her eight colleagues in the Group of 9 were closer to the Governor and more sympathetic to his numerous requests concerning the finances of the State especially the one on raising a huge bond from the capital market in 2010. Disturbingly, the State House of Assembly was prevented from meeting for well over five months until March 2011 when the Group of 9, once described by Daniel as "my boys", passed the N106 billion state budget for 2011 (The Punch, March 11, 2011, p. 80). Curiously, the group, among other several other constitutional violations, met without the official mace of authority.

Quite importantly, the 2011 national budget, the last before the next round of general elections, clearly showed that both the Presidency and the parliament have learnt little or nothing from the consequences of the shoddy budgetary processes in the past eleven years. Like in the recent past, the legislators not only raised the budget benchmark of the international market price of crude oil per barrel, but also raised the estimated oil sales without sufficient explanations. In essence, it means that rather than signal the beginning of fiscal consolidation that Nigeria needs badly in its critical moment, the 2011 financial plan appears to be another expansionary and unimplementable budget that is likely to be rendered ineffective by the boom and bust activities of the volatile oil market (The Punch, March 28, 2011, p.14).

Finally, greater freedom of expression will encourage scrutiny and the activities of "whistle blowers" who are unofficial monitors of governmental activities. In the light of this, it should be appropriate to critically examine efforts of successive administrations in the Fourth Republic on the passage of the Freedom of Information (Fol) Bill in Nigeria. The most publicized efforts on the Fol bill started in 2003, and after a long, windy and bumpy journey the piece of legislation was not signed into law by the then President Obasanjo in 2007. Again, after a long wait, the bill that was passed to President Goodluck Jonathan in March 2011 had not been signed as at the first week in April. Undoubtedly, the passage of the Fol bill, which should give access to wide ranging information on public procurements, revenue generation and spending, is supposed to help in building fiscal and democratic consolidation as well as overall development in Nigeria.

\section{CONCLUDING REMARKS}

The twelve-year old democratization (1999-2011) in Nigeria's Fourth Republic, so far seems, to show that the edifice of democracy is already in place in the country.
However, the consolidation of democratic principles and, especially democratic rule, requires a more conscious effort of developing such basic principles as public accountability and transparency. Indeed, fiscal responsibility and public accountability are, undoubtedly, the hallmarks of democracy that should bring about national development in the country. The challenges of patrimonialism, patron-client networks and the faulty leadership recruitment, which have all combined with other similar factors to constitute major impediments to the democratization process in Nigeria's Fourth Republic can, however, be effectively addressed by the conscious engagement of more professionals from diverse backgrounds in public affairs and governance in the country. This should preferably, start from the local community levels; and "local" in this paper can be defined as any particular location or position of public or private authority in which an individual finds himself or herself. The net effect of this is that the society shall gradually be developed through the individual activities of important stakeholders from across the public and private sectors of the country. In addition, civil society organizations and Nigerians in the diaspora who have experienced best practices in other parts of the world should be more engaged in public affairs for the overall development of Nigeria.

\section{REFERENCES}

Adejumobi A (1985). Bureaucrats and Accountability, in Eniola Adeniyi and Sunday Titilola (eds) Leadership and National Development, Ibadan: Nigerian Institute of Social and Economic Research (NISER)

Ake C (1996). Democracy and Development in Africa, Ibadan, Nigeria: Spectrum Books.

Asiwaju Al (2000). "Sharing Best Practice Experiences in DemocracyBuilding in Non-French Speaking African States", draft paper presented at the $4^{\text {th }}$ International Conference on New and Emerging Democracies, Cotonou, Benin Republic, December 4-6.

Callaghy $T$ (1987). The State as a Lame Leviathan: The Patrimonial Administrative State in Africa, in Zaki Ergas (ed.) The African State in Transition, New York: St. Martin's Press.

Diamond L, Oyediran O, and Kirk-Greene A (eds.) (1999). Transition without End: Nigerian Politics and Civil Society Under Babangida, Ibadan: Vantage Publishers.

Dudley BJ (1973). Instability and Political Order: Politics and Crisis in Nigeria, Ibadan University Press.

Ekeh P (1975). Colonialism and the two publics in Africa: A Theoretical Statement. Comp. Stud. Soc. Hist. 17(1):91-112.

Ergas Z (1987). Transition, in Zaki Ergas (ed.) The African State...op cit.

Ezekwesili $O$ (2011). "Enough of the failing upward syndrome!', Sunday Punch, March 6, p.19

Holmes M (1998). The Public Expenditure Management Handbook, Washington, D.C: World Bank.

Ikpe UB (2005). Towards Explaining the Continuing Dominance of Patrimonial Exchanges in State-Society Relations in Nigeria: The Relevance of the Ethno-Patrimonial Incorporation Model, Unilag Journal of Politics, University of Lagos, Nigeria, 2(2): 5-35.

Jinadu LA (2010).Separation of Powers and the Budgetary Process in Nigeria: Tentative Conjectures, in Lai Olurode (ed.) Reflections on a Decade of Democratization in Nigeria, Lagos: Friedrich Ebert Stiftung Foundation.

Joseph R (1991). Democracy and Prebendal Politics in Nigeria: The 
Rise and fall of the Second Republic, Ibadan: Spectrum Books.

Kiragu K (2002). Public Financial Management, in Ladipo Adamolekun (ed.) Public Administration in Africa, Ibadan: Spectrum Books

Lewis A (1965). Politics in West Africa, Toronto \& New York: Oxford University Press.

Mimiko NO (2010). "How do we build and sustain democracy in Nigeria", Keynote address at the launching of a book - The State and Governance Crisis in Nigeria, University of Ibadan, December 4.

Nnoli O (ed.) (1981). Path to Nigerian Development, CODESRIA Book Series, Dakar, Senegal.

Nyong BE (2000). Relationship among the Three Arms of Government in Nigeria, in Okon E. Uya(ed.) Civil Society and Consolidation of Democracy in Nigeria, Calabar: CATS Publishers.

Olopenia RA (1998). A Political Economy of Corruption and Underdevelopment in Nigeria, Faculty of the Social Sciences, Lecture
Series, No. 10, University of Ibadan, Nigeria, October 7.

Olowu D (2002). Accountability and Transparency, in Ladipo Adamolekun (ed.) Public Administration in Africa ... op cit

Onuoha B (2007). Policy Reforms in Nigeria: Contradictions and Challenges for Implementation, in Remi Arifowose and Tunde Babawale (eds.) Nigeria Beyond 2007: Issues, Challenges and Prospects, Lagos: Concept Publications.

Theobald R (1990). Corruption, Development and Underdevelopment, Durham: Duke University Press.

Wildavsky A (1975). Budgeting: A Comparative Theory of the Budgetary Process, Boston: Little Brown \& Co.

Yagboyaju DA (2009). Public Sector Reforms, in Isaac O. Albert (ed.) Praxis of Political Concepts and Cliches in Nigeria's Fourth Republic, Ibadan, Nigeria: Bookscraft. 